\title{
Climate change, here and now
}

\author{
Poor nations need the data that show what is already happening to their climate, as well as the \\ resources with which to adapt to change.
}

C ritics are always ready to accuse the Intergovernmental Panel on Climate Change (IPCC) of exaggeration. The content of its sobering 6 April report on climate-change impacts, adaptation and vulnerability (see page 706) offers little support to such criticism. But the panel is, from time to time, guilty of almost absurd understatement.

While discussing the encouraging growth in real data applicable to the study of climate change, Working Group II of the IPCC points with regret to a "notable lack of geographic balance in data and literature on observed [climate] changes, with marked scarcity in developing countries". A few pages later, a figure in the report reveals that of 28,671 "significant observed changes in biological systems" from around the globe of which the report made use, 28,115 originated from Europe. Just two were from Africa.

This disparity is all the more alarming because, as the report makes clear, it is in Africa and other parts of the developing world that such data are most sorely needed. They are required not as proof of the global reality of change - that debate is over - but as guidance to policies and interventions that are needed, not in a far-off world of melted ice caps, but right now. The data are needed so that policymakers can know what is happening to crops, to river flow, to soil moisture, and make appropriate use of that information.

In terms of its scope, anthropogenic climate change is unlike any problem previously faced by humanity. Its effects are already felt worldwide and will last for centuries. Solutions to its primary cause - the release of carbon dioxide from the burning of fossil fuels - are measured in terms of trillions of dollars of investment taking place over decades. Yet it also has more immediate, short-term implications. Working Group II predicts with high confidence that, by 2020, between 75 million and 220 million Africans will suffer from increased water stress due to climate change. In the same period, in some African countries, yields from rain-fed agriculture could be halved.

The qualitative sense in which 2020 can be clearly set down as the

\section{Science without borders}

\section{Researchers should push for rule changes to make Europe work as one.}

f European science is to prosper, the barriers that prevent seamless interactions between scientists in different nations need to come down. Last week, the European Commission published a 'green paper' on the future of the European Research Area, the entity it created to improve such interactions. Scientists must now engage in the consultation process that will follow from this document and so help resolve the problems that currently constrain 'cross-border' science. 'short term' is that predictions made in the report for that date are not conditional. They do not depend on action or inaction on greenhouse-gas emissions between now and then. Rather, they are immune to anything being done about emissions at any point. If the industrial nations were to start slashing their emissions on 1 May of this year, the prognosis would be the same, because the degree of change to be expected through to 2020 is already pretty well fixed by the current state of the climate system.

This is not for a moment to say that there is no point in reducing emissions. That must remain a central objective in attempting to get the planet's climate under control. But Working Group II's report makes clear that this is not enough.

Developing countries also need assistance that will help them adapt to effects of climate change that are already on the way. Although some of this may be focused on climate-specific approaches (see page 716), most of it can best be
"Developing countries need assistance to help them adapt to effects of climate change that are already on the way." achieved through conventional aid programmes aimed at economic development, agricultural robustness and primary health care. Better off, healthier people are people more likely to have the resources needed to adapt.

Both developed and developing countries also need far better data about what is happening in their territories. Entire areas of study, such as the retreat of permafrost (see page 718), remain bereft of appropriate data sets.

And energy sources and patterns of use must shift to lessen the ultimate extent of climate change. But the world also needs to take action right now against the harm that is already being done. The IPCC's latest report provides yet another reason to seek development pathways out of the pitiless poverty in which far too much of humanity is trapped.

The European Research Area is a somewhat nebulous concept, most readily described as the highly fragmented arena within which European Union scientists work, in both public and private sectors. But it is a concept that matters, in determining how easily a European researcher can operate across national borders.

Current deficiencies in the way the area works are most apparent when they are personal. One German biology professor, for example, was recently courted by a university in the Netherlands. Aware of the advantages the prestigious post held for his research ambitions, the professor was sufficiently enthusiastic to accept a small salary cut. But negotiations collapsed because Dutch regulations made it impossible for him to bring his German pension to the new position.

On a broader level, those seeking to create expensive items of 
scientific infrastructure to serve the whole continent, such as a biobank of gene or tissue samples, are often dismayed to find that there is no appropriate source of funding - no matter how useful the project. Scientists in Europe also find that the management of intellectual-property rights varies between the member states. Scores of issues such as these make it hard for researchers to properly exploit the scale of the European Research Area.

Overcoming such obstacles is rightly seen as important in the European Union's push to become more scientifically competitive with the United States, where scientists already enjoy the advantages of ready interaction with a vast array of colleagues in a nation of 300 million people.

The green paper released by the European Commission on 4 April outlines the existing problems and asks for ideas from interested parties, including scientists, on what should be done to fix them. The consultation process will include a questionnaire that will appear on the commission's website (htp://ec.europa.eu/research/era) from 1 May until August, and a conference in Portugal this autumn. Early next year, the commission will use this feedback to help it draw up decrees or legislation that it thinks will help strengthen the European Research Area.

But the commission does not have the clout to implement such reforms on its own. Its main political master, the Council of Ministers, committed itself in 2000 to improving competitivity in research and innovation by 2010 - by facilitating the mobility of researchers, for example. But the member states whose leaders make up the council have not yet implemented the changes in their home countries that are needed for the European Research Area to function effectively.

The European Commission, whose Framework research programmes still account for only about one-twentieth of the member states' total spending on research, can do little more than encourage national governments to realize that far more cooperation at the European level will benefit them all. Perhaps the most sensitive issue in this regard is to get more national tax revenue to be pooled for genuinely European projects.

None of these problems will be solved overnight. But it is important that the commission gains the explicit support of both industrial and academic scientists in its long march towards European research unity. The consultation will allow individual researchers to put on the record the cross-border issues that confront them in their working lives. As many as possible should fill in the questionnaire and make their voices heard.

\section{When employees attack}

\section{Government scientists should be able to comment publicly - within reason.}

B admouthing one's government is a fashionable pastime in some parts of the world. Many US climatologists, even those who receive federal funding, have grave reservations about the White House's continued neglect of international climate agreements, and they aren't shy about saying so. In Britain, meanwhile, scientists as well as political analysts have been quick to criticize the government's plan to spend billions on renewing the national fleet of nuclear-weapons submarines.

Roll those two examples together, and transplant them into a society where freedom of speech is often seen as being under pressure from several directions, and you get the case of Claudio Mendoza. Until recently the head of a government physics laboratory in Venezuela, Mendoza has been demoted after making sarcastic comments about the government over what he regards as its tendency to ignore scientists and their advice (see page 711).

What infuriated Mendoza's paymasters most was probably his suggestion - made in a newspaper article promoting a play about nuclear weapons - that president Hugo Chávez might want to pursue a nuclear-weapons programme and that, if he did so, he was liable to fail because of this alleged disdain for expert advice.

Mendoza's comments were not made in any official capacity (his article was signed, with no affiliation given), raising the fraught question of whether senior government scientists should be free to make disparaging public comments about the state institutions that they serve, when they are away from work.

On a facile level, this is a disagreement about whether it is acceptable for someone to be fired because their bosses can't take a joke. In many countries, acerbic comments about the machinations of politics are a valid and effective mode of public discourse.

But, of course, a line has to be drawn somewhere. It is hard to escape the feeling that, in this case, it has been drawn in the wrong place. Many civil servants in other countries might expect a dressing-down if they behaved in this way, but might justifiably argue that they have a right to express a grievance. The message coming from Mendoza's bosses within the Venezuelan national research institute is an unsavoury one. His removal from a management position implies that someone who voices contrary opinions is not fit to be a lab head. What's more, Mendoza has been warned that he had better clam up if he doesn't want to lose his job altogether.

The play that Mendoza was writing about was Michael Frayn's Copenhagen, the international hit that deals with a crucial 1941 meeting between Niels Bohr and Werner Heisenberg, and their struggle to comprehend the feasibility and consequences of developing nuclear weapons during the Second World War (see Nature 394, 735; 1998).

One of the reasons for the play's success was general interest in what physicists of Bohr's generation thought about the issues surrounding nuclear weapons. Of course, these thoughts only became public some time after the United States had built and used the bomb. But times have moved on, and people in Caracas, as elsewhere, would benefit if their scientists were be able to participate openly in public debate on nuclear policy. 